NOTE: This is an Accepted Manuscript of an article published by Taylor \& Francis Group. Full citation and link to published formatted article:

Hooghe, M., \& Oser, J. (2016). Trade union density and social expenditure: a longitudinal analysis of policy feedback effects in OECD countries, 1980-2010. Journal of European Public Policy, 23(10), 1520-1542. http://dx.doi.org/10.1080/13501763.2015.1102952.

\title{
Trade union density and social expenditure: a longitudinal analysis of policy feedback effects in OECD countries, 1980-2010
}

\author{
Marc Hooghe and Jennifer Oser
}

\begin{abstract}
Two causal mechanisms have been invoked to explain the positive correlation between union membership and social expenditure. Unions try to influence policy, but they are also more successful in mobilizing members in economic systems in which actors engage in coordinated strategic interaction. Applying insights from the policy feedback and comparative capitalism literatures, our analysis indicates that union density is a determinant of social expenditure. A strong policy feedback effect is also present whereby social expenditure has a positive effect on union density. We find a positive effect of union density on social expenditure in coordinated market economies (CME's), but not in liberal market economies (LME's). We discuss the implications of these findings for citizens' capacity to influence policy in varied contexts and for the 'varieties of capitalism' literature, and we close with some speculation about the implications of these findings in the current economic downturn.
\end{abstract}

\section{KEYWORDS}

Collective policy actors; policy effects; policy feedback; social expenditure; trade unions; varieties of capitalism. 


\section{INTRODUCTION}

Trade unions have played a quintessential role in the development of contemporary welfare regimes (Boeri, Brugiavini and Calmfors 2001; Regini and Esping-Andersen 1980). It has been shown that trade unions have an effect on economic performance (Golden 1993), wage levels and unemployment (Checchi and Nunziata 2011), and levels of social protection (Donado and Wälde 2012). Although it has been argued that trade unions have lost much of their political power in the most recent era, a variety of studies have suggested that unions still have a meaningful impact on social policy (Béland 2001; Bradley et al. 2003; Zárate Tenorio, 2014). The question of how exactly trade unions can affect social policy is all the more salient in the current economic climate, which is characterized by a general decline in union density and welfare state retrenchment in numerous countries (Gumbrell-McCormick and Hyman 2013).

A theoretically relevant way to explain the policy effect of trade unions is to apply insights from the literature on trade unions as a collective policy actor. In the literature on the policy effects of collective mobilization, a recurrent focus is on the way collective actors use opportunities that are offered by the political system (Richardson 2000). Furthermore, it has been argued that the state itself should also be seen as an autonomous actor, pursuing its own goals (Evans, Rueschemeyer, and Skocpol 1985). Scholarship on policy feedback mechanisms has shown that government policy is not just a reaction to outside pressures, but might also have an effect on the organizing potential of collective policy actors (Campbell 2003).

Although the literature indicates that a policy feedback effect between collective actors and state policy is plausible, this has rarely been examined cross-nationally. While crossnational research has shown that feminist movements have had an effect on government policy (Htun and Weldon 2012), other research suggests that the causal arrow can be reversed by examining whether government policies aimed at promoting gender equality encourage the development of feminist organizations in what has been called 'state feminism' (McBride and 
Mazur 1995). A similar logic can be applied to trade unions, as earlier studies have shown that specific elements of the political system have an effect on trade union density (Ebbinghaus, Gobel, and Koos 2011).

There is no reason to expect, however, that for trade union this relationship will operate in the same manner in different national contexts. The comparative capitalism literature suggests that there are substantial differences between economic systems with regard to the prevailing interaction and coordination styles between market and state actors (Hall \& Soskice 2001). We expect that in market economies that are characterized by a high level of coordination among actors, there is more likely to be a positive feedback relationship between union density and social expenditure in comparison to liberal market economies that are characterized by minimal actor coordination. The study therefore investigates union impact on state policy in varied market economies, as well as the reverse effect, which might be labeled a form of 'state unionism'. We do so by conducting a time series analysis on data for thirty OECD countries, for the period 1980-2010. As previous research shows that trade unions have strong policy effects (Jensen 2012), we can assume that unions offer an excellent case to investigate the occurrence of these policy feedback effects.

In this article we first provide an overview on the literature with regard to policy feedback effects, and the relationship between trade unions and social policy. Subsequently we present data, methods and findings. The concluding discussion reviews the implications for the relation between trade unions, social expenditure and market coordination.

\section{POLICY FEEDBACK EFFECTS AND VARIETIES OF CAPITALISM}

Prior research has confirmed that collective actors can have an effect on government policy (Cheon and Urpelainen 2013; Hill, Leighley, and Hinton-Andersson 1995). For example, Htun and Weldon's (2012) comparative investigation of the effect of feminist mobilization on 
policies regarding violence against women provides compelling evidence of the impact of mobilization campaigns on government policy. However, most of the studies on this topic fail to include a test for possible feedback effects (McBride \& Mazur 1995).

Including an empirical assessment of feedback effects is important because the crosssectional correlation between mobilization levels and specific policies does not inform us about the causal logic involved. A rich tradition of policy feedback research recognizes that just as politics may influence policies, it is equally plausible that policies have over-time effects on political mobilization (Campbell 2003). The feedback approach can enrich prior research of union mobilization on social policy by drawing on the insight that the state, or specific government policies, should also be considered as independent variables that can have an effect on social actors. Historical institutional research that shaped this field of study focused primarily on highlighting one direction of the effect, namely the impact of policies on interest groups (Pierson 1994, 2000). Subsequent feedback research has investigated the reciprocal relationship between specific policies on the one hand, and mass publics' attitudes and behavior on the other (Campbell 2003; Hooghe and Meeusen 2013). This kind of research suggests an ongoing equilibrium relation between the state and policy actors.

The scholarship on trade unions has hinted at the fact that institutional factors might have an effect on union density (Ebbinghaus, Gobel, and Koos 2011), but the potential existence of a feedback effect has yet to be systematically studied. Policy effects of trade unions will be strongly dependent on the nature of policy-making arrangements within a political-economic system. Especially in neo-corporatist or consociational political systems, trade unions are expected to have a stronger effect on public policy (Molina and Rhodes 2002).

To investigate the impact of political-economic context, we draw on the "varieties of capitalism' literature (Hall and Soskise 2001). The main idea in this research line is that specific arrangements between the state and economic actors tend to be stable over time and lead to the 
occurrence of different typologies with regard to the political economy of a country (Thelen 2012). Some economic systems are characterized by a high level of coordination between the state, policy actors and economic actors, whereas strategic coordination in other systems is largely left to market forces (Hall and Soskice 2001; Thelen 2012). Although some of the research literature has expanded the original typology, the main thrust of the varieties of capitalism theoretical framework locates countries at two ends of a spectrum based on whether or not economic coordination is left only to market forces, or alternatively, whether strategic actors are involved in coordination mechanisms. In liberal market economies (LME's), competitive markets are the prevailing force that governs the relationship between firms and other economic actors in society. On the other end of the spectrum, in coordinated market economies (CME's) the different actors in the political economy are engaged in coordinated strategic interaction (Hall and Gingerich 2009). In systems in which actors operate in concert, it is more likely that trade unions will have an effect on the functioning of the economy and on mechanisms of redistribution (Jensen 2011). Given the stable equilibrium of these coordination mechanisms, trade unions would stand to benefit from their strategic role in these coordination mechanisms.

Within the varieties of capitalism literature, research has been concentrated overwhelmingly on the behavior of private firms, while the role of trade unions as a 'minor actor' has remained nearly invisible (Howell 2003, 112). The goal of the current analysis is to investigate whether the mechanisms that have been identified for private firms also apply for trade unions. It can be assumed that trade unions have a preference for redistributive policies (Iversen 2008, 291). In those political economies where non-market forces play a role in economic coordination, a positive relation between trade union strength and social policy can be explained by an institutional equilibrium. On the one hand, trade unions can have an effect on governmental policy (Boreham, Hall and Leet 1996), but one can just as well assume that 
trade unions will be able to consolidate their position if they are involved in economic coordination. A typical example would be their involvement in the administration of redistributive policies, as is a typical feature of the Ghent system that occurs only in coordinated market economies (Ebbinghaus, Gobel \& Koos 2011). These observations lead us to expect that the relationship between trade unions and social policy will be stronger in coordinated market economies.

Trade unions offer an ideal case to investigate feedback effects between mobilization and policy outcomes as research shows that unions are collective policy actors that represent specific interests in order to achieve policy goals. Power-resource theory, too, attributes levels of equality and social solidarity to the strength of the labor movement (Korpi 1989). Trade unions pursue multiple social policy goals that focus on advocating for the social and political rights of the labor population (Boeri, Brugiavini, and Calmfors 2001; Lindvall 2013). In numerous countries, trade unions explicitly aim to influence social policy (GumbrellMcCormick and Hyman 2013).

The strength of trade unions in influencing social policy has, however, been a subject of debate in the literature. Research has shown that alternative factors such as economic development and institutional arrangements can be equally important predictors of social spending (Huber and Stephens 2001; Kittel and Obinger 2003). Despite the credibility of alternate causes, the capacity of trade unions to influence social policy has been demonstrated in a number of cross-national studies (Boreham, Hall and Leet 1996; Bradley et al. 2003; Pontusson 2013).

While many studies have investigated the impact of trade unions on social policy, the feedback effect of social policy on trade unions has received little attention. A possible explanation for why feedback may occur is due to the self-interest of affected constituencies, who have positive incentives to remain mobilized in order to advocate politically for the 
continuation of generous social policies (Pierson 1994). In the present study, we do not aim to specify the precise mechanisms at play. Instead, we pursue the more modest goal of determining whether evidence can be found for the existence of such feedback effects, and whether feedback effects operate differently in different political-economic contexts.

\section{RESEARCH DESIGN AND HYPOTHESES}

In this paper, union strength is operationalized as union density, which is commonly considered a reliable proxy for union strength (Lindvall 2013). This allows us to rely on standardized international measurements from the International Labor Organisation. In a separate analysis, and as a robustness check, we also investigated whether the strike activity of trade unions has an effect on social expenditure. The literature suggests that trade unions do not just have direct policy effects but can also exert their influence in a more indirect manner through their potential to mobilize the electorate (Radcliff and Davis 2000). Since trade union membership is positively associated with electoral turnout levels-particularly for lower-income and lesseducated voters (Flavin and Radcliff 2011; Leighley and Nagler 2007)—unions are likely to put pressure on government coalitions to adopt more expansive social programs. It is important therefore also to take into account the level of voter turnout and the role of left political parties in our analysis.

The policy effect we investigate is a measure of total social expenditure, which serves as a comprehensive indicator for the coverage offered by the welfare state (Kittel and Obinger 2003). Since the overall expenditure measure is considered a very useful reflection of social policy decisions (Siegel 2007), it is an appropriate outcome of interest given the theoretical interest of our study. Indeed the major studies in the field about the relationship between political actors and economic redistribution rely on this indicator (Jensen 2011). Although some research has taken advantage of disaggregated categories of social expenditure (Kuitto 2011), 
the demarcation of sub-categories of spending can create problems in cross-national comparability. In line with earlier studies, we therefore opt for a comprehensive measure of social expenditure (Huber and Stephens 2001; Swank 1988).

As noted by Howell (2003), trade unions have not received particular attention in the varieties of capitalism literature. Yet, we contend that the two main varieties of capitalism lead to clear expectations regarding how the relationship between trade unions and social policy may systematically differ by context. Trade unions can be expected to have a stronger effect in contexts in which they are considered as one of the strategic actors coordinating political and economic outcomes. We also expect to find a policy feedback effect whereby levels of social expenditure are positively related to trade union strength, and we assume that this relationship will be stronger in coordinated market economies.

A very specific element in the relation between trade unions and coordinated market economies is the existence of the Ghent system (Ebbinghaus, Gobel and Koos 2011). This system of a union-administered unemployment system provides important selective incentives for becoming a union member in a number of coordinated market economies - namely in Finland, Sweden and Denmark, and also partially in Belgium (Van Rie, Marx and Horemans 2011). In countries applying the Ghent system, the correlation between trade union density and social expenditure should be even stronger than in other coordinated market economies.

These considerations lead to the main hypotheses in this paper:

H1. The level of union density in a country is a significant determinant of the level of social expenditure.

In order to take account of a feedback effect, we also include a second hypothesis:

H2. The level of social expenditure in a country is a significant determinant of the level of union density. 
In addition, we investigate whether the relationship between union density and social expenditure is dependent upon the type of market coordination in a country:

H3. The association between social expenditure and the level of union density is stronger in countries with a coordinated market economy than in countries with liberal market economies.

\section{DATA AND METHODOLOGY}

We have compiled a time series cross-sectional data set that spans the years 1980 to 2010 . The 30 countries in the data set include all major OECD countries for which full data are available. Our main analysis includes all 30 countries, and we also estimated a parallel set of models for the 20 largest OECD countries in order to estimate whether the analysis might be unduly influenced by small OECD economies (Hall and Soskice 2001, 19-21). Findings for this subgroup were consistent with those for the overall sample, and can be viewed in the Online Appendix (Tables A2 and A3). ${ }^{1}$

Our analysis includes both pooled ordinary least squares (OLS) random effects and fixed-effects estimations in order to capitalize on the respective advantages of each approach (OECD 2011). The pooled random effects approach has the advantage of utilizing cross-country variation in both the independent and dependent variables. Thus, social expenditure in countries with high union density may be compared to that in less unionized countries. An additional advantage of the random effects approach is that it can include time-invariant variables (such as market economy types), and therefore models that estimate the interaction effects of market economy use this approach. One disadvantage to the pooled random effects approach is that it may entail omitted variable bias, as unmeasured time-invariant country characteristics may be missing from the model. We therefore include a second set of models that include country fixed 
effects in order to eliminate cross-country variation. The fixed-effects models are informed exclusively by within-country comparisons, and therefore identify country-specific variation over time. A disadvantage of the fixed effects approach is that time-invariant variables (such as the market economy type or Ghent system) cannot be included in these models, since the analysis focuses on over-time variation. The OLS and fixed effects models are therefore often used in concert in order to benefit from the unique advantages of each approach (Wooldridge 2010). Analyses of time-series cross-sectional data are known to suffer from potential violations of OLS assumptions, namely auto-correlation, heteroskedasticity and cross-sectional dependence (Beck and Katz 1995). To address this, we follow the common approach of using Driscoll-Kraay standard errors, which adjust the standard errors to be robust (Cheon and Urpelainen 2013; Driscoll and Kraay 1998).

The main political control variables are government party orientation and voter turnout, and we also use standard control variables of GDP per capita, GDP growth, and time trends (see Online Appendix Table A1 for descriptive statistics).

\section{Variables used in the analysis}

Social expenditure. Social expenditure is measured as a percentage of GDP, as documented for the period 1980 to 2010 by the Social Expenditure Database (SocX) of the Organization for Economic Co-operation and Development (OECD 2014). These data encompass the largest scope of social spending that is standardized for international comparison (Jensen 2011; Siegel 2007). The SocX data is gathered by country, and the total social expenditure measure is a composite of four broad spending categories (pensions; income support to the working-age population; health expenditures; and all other social service expenditures).

Trade union density. Trade union density is an indicator of the strength of the trade union movement in terms of the degree to which workers are organized, and the International Labor 
Organization (ILO) has standardized the data across countries (Hayter and Stoevska 2011). We use the measure from Visser's Database on Institutional Characteristics of Trade Unions, Wage Setting, State and Intervention and Social Pacts (ICTWSS) (Visser 2013). The union density rate we use in this study is measured as the net union membership as a proportion of employed wage and salary earners.

Government party orientation. The orientation of the ruling executive party can exert an independent influence on social expenditure, with left-oriented parties expected to enact higher social expenditures (Castles and Obinger 2007; Hicks and Swank 1992). To control for this factor we use the World Bank's Database of Political Institution's measure of the party orientation of the executive (Keefer 2013). We code this as a dichotomous variable, with the left party in power (1), or not (0).

Voter turnout. Turnout level has been shown to be positively correlated with social expenditure (Hicks and Swank 1992; Larcinese 2007). We therefore control for turnout level using voter turnout data from the Institute for Democracy and Electoral Assistance (IDEA).

GDP per capita and GDP growth. We include GDP per capita in the model (measured in thousands of dollars) to control for the possibility that social expenditure is associated with economic development. We also control for GDP growth (measured as a percentage change) to account for the possibility that governments adjust social policy in response to economic fluctuation.

Time trend. Since we know that trade union density has decreased over time while social expenditure has increased, we add a time trend variable that controls for the number of years elapsed since 1980 .

Varieties of capitalism. The identification of the two ideal types of political economies reviewed above (Liberal Market Economies versus Coordinated Market Economies) is the core distinction in this theory (Hall and Soskice 2001, 8). We limit our analyses to the distinction 
between LME's and CME's since the theoretical implications of these two types of capitalism on the main variables in our analysis are clear. Typical examples of liberal market economies are the U.S., Canada, and Australia, while Belgium, Sweden and Japan are examples of coordinated market economies.

Ghent system. Since the full Ghent system is practiced in Finland, Sweden and Denmark these countries are assigned a value of ' 1 '. In addition, since Belgium also partially uses this system (Van Rie, Marx \& Horemans 2011), it receives a score of .50 on this variable.

Additional control variables: While the variables reviewed above include the main control variables, we test the robustness of our findings by including a set of additional controls, including exposure to foreign trade, unemployment rates, proportion of old age population, location of citizens (as urban residents are easier to organize) and structure of the economy (including factors like percent value added from industry, minerals, agriculture and services).

\section{ANALYSIS AND FINDINGS}

Our analysis is carried out in two main steps. First, we estimate pooled random effects OLS and fixed-effects regression models to explore the determinants of social expenditure. We also explore interactions between union density and type of political economy. Second, we turn the analytical arrow by investigating the impact of social expenditure on trade union density (with the same test for impact in different types of political economies). Although time horizons for expected impacts on different kinds of expenditure is expected to vary, we follow the common practice of including a time-lag specification of the key explanatory variables by one year to allow for capturing delayed effects (De Deken and Kittel 2007). Additional analyses that were conducted with time lags of two and three years yield consistent findings. 


\section{Trade union density as a determinant of social expenditure}

First, we use union density to explain the level of social expenditure (Table 1). The findings show that there is a significant relationship between union density and social expenditure, controlling for national level characteristics. The findings for the pooled random effects analysis that includes the main political control variables (Model 1) show that for every percentage point increase in union density, total social expenditure as a percentage of GDP increases by .12 percentage points. When a one-year lag is added for union density (Model 2), the effect stays more or less the same.

The findings hold when additional controls are added in Models 3 and 4, namely the structure of the economy (agriculture, industry and minerals), exposure to foreign trade, urban concentration of residents, proportion of old age population and unemployment. While adding these new controls in many cases diminishes the coefficient size of other controls in the model the effect of key test variables remains sizeable, and for the sake of parsimony in Models 5 through 8 we present the findings for the more conservative test only, of union density as a lagged independent variable (Union density $\mathrm{t}_{\mathrm{t}}$ ). In Model 5, it can be observed that coordinated market economies have a strong positive effect on social expenditure. Including the Ghent model as an independent variable (Model 6) shows an even stronger effect of having this system of trade union involvement in administering social security. The conclusion remains that trade union density and social expenditure are strongly associated, lending support to Hypothesis 1.

[Table 1 about here]

When country fixed effects are introduced to control for all time-invariant country characteristics (Table 2), the findings are no longer informed by cross-country variation, but rather tell us about the relationship between union density and social expenditure within a given 
country over time. The findings suggest that union density has a positive association with social expenditure within countries over time. Similar to the pooled random effects models, the findings for the key test variable of union density and lagged union density remain robust when additional control variables are included. Moreover, we see that the two main political control variables of the political orientation of the party in power and voter turnout are not significant (Models 1 and 2). The additional control variables are often significant, in the expected direction, but they do not take away the explanatory power of the key independent variables (Models 3 and 4). As the fixed-effects specification analyzes over-time changes within countries, the models in Table 2 cannot include information about the coordination of the market economy and the Ghent system (as we did in Table 1), as these are time-invariant country characteristics.

[Table 2 about here]

Additional models were estimated to test whether strike activity or the public and private nature of labor unions may affect the impact of union density. To control for the activity of labor unions (beyond sheer membership), the International Labor Organization's strike count was included as a control variable. The findings show that strike activity has no discernible effect on social expenditure (see Online Appendix, Table A4).

Our expectation, however, was that trade union density would have a stronger effect in coordinated market economies (Hypothesis 3). The interaction findings for the relationship between the type of political economy and union density suggest a strong interaction effect on social expenditure (Online Appendix Table A5). The main effect of coordinated market economies on social expenditure is strong and positive (Model 1), and in the interaction analysis (Model 2), the interaction term is highly significant, suggesting a strong association between 
union density and social expenditure in coordinated market economies. This interaction effect is illustrated in Figure 1, which shows that a strong association between trade union density and social expenditure is present only in the coordinated market economies.

[Figure 1 about here]

\section{The feedback effect: Social expenditure as a determinant of trade union density}

Our second hypothesis departs from the opposite causal logic, assuming that high levels of social expenditure render it easier for trade unions to mobilize members. In Table 3, therefore, trade union density is now the dependent variable. The structure of the regression, however, remains the same as in Tables 1 and 2, including a one-year time lag of the theoretically-relevant independent variable (in this case, social expenditure).

Similar to the previous analysis, the findings for the pooled random effects analysis (Table 3) show that social expenditure has a significant effect on union density. The model that includes the main political control variables (Model 1) shows that for every percentage point increase in social expenditure, union density increases by 1.25 percentage points. This relationship also holds with an added time lag (Model 2). Including the by now familiar series of control variables (Models 3 and 4) does not changes the theoretically relevant relations. In Model 5 we again control for whether a country can be considered a coordinated market economy or not and this sharply reduces the number of observations. While the effect of having a coordinated market economy is positive, including this variable does not have an impact on the effect of social expenditure. Including the Ghent system (Model 6) shows a very strong effect.

[Table 3 about here] 
In Table 4 we again repeat the same analysis, but this time with country-fixed effects. These models, too, confirm a positive effect of social expenditure on trade union density. As noted, these fixed effects models cannot control for the time-invariant factors of coordinated market economy and the Ghent system, but beyond this limitation, these country fixed-effects models confirm the findings from the pooled random effects analysis. Ideally, for this analysis too, we would like to have tested the occurrence of interaction effects with the indicators on the varieties of capitalism. Both the analyses with the 'coordinated market economy' variable, as with the Ghent system variable, however, proved to be plagued by unacceptably high levels of multicollinearity. Given the very high scores of the Ghent model variable in Table 4, this does not come as a surprise. Therefore, it was impossible to test the occurrence of interaction effects in this part of the analysis.

[Table 4 here]

\section{DISCUSSION}

This study contributes to scholarship that demonstrates an effect of collective actors on policy. From an empirical perspective, this research confirms and expands upon prior findings on the impact of trade union membership on social policy. We have shown that, despite the wellstudied weakening of trade unions' capacity to achieve policy aims in recent years, the general pattern still holds. Second, the study adds nuance to scholarship on collective actors and policy feedback effects by showing that social policy has an effect on trade unions as mobilizing social movements that recruit members. As large- $\mathrm{N}$ empirical studies on the effect of citizen engagement on policy continue to contribute to cutting-edge findings on this topic, the present study serves as a timely reminder of the early policy feedback literature's main theoretical message: in addition to the standard causal logic that politics impacts upon policy, our research designs must also attempt to grapple with the possibility that policy can impact upon politics. 
Third, the findings indicate the importance of political and economic context for the relationship between citizen engagement and policy outcomes by showing that a positive reciprocal feedback effect of trade unions on social expenditure can be identified in some contexts (i.e. coordinated market economies) but not in others (i.e. liberal market economies).

A main empirical goal of the current paper is to ascertain whether trade union density is associated with social expenditure. The analysis has made clear that trade union density is a significant determinant of the level of social expenditure, and that this effect is prominent in political systems where actors coordinate to make strategic economic decisions. This interaction effect renders plausible the claim that it is mainly because of their political influence that trade unions will also have an effect on the level of social expenditure. In liberal market economies, where coordinated economic decision-making is not taking place, trade unions lack the necessary tools to have an impact on social expenditure. By controlling for the executive's party orientation, voter turnout, economic growth and development, as well as all time-invariant country characteristics, we may rule out the possibility that the association is due to these factors. The robustness of the findings when the union density variable is lagged is suggestive of a causal relationship, and the inclusion of a variety of additional control variables did not diminish the association between the key test variables.

When we reverse the causal logic of the analysis, it can be observed that levels of social expenditure have an effect on trade union density. In this feedback effect direction of the analysis, the limitations of the data are more apparent in efforts to determine interaction effects. While we can observe a direct effect of coordinated market economies, and especially of having a Ghent system, on trade union density, problems of multicollinearity prevented us from testing an interaction effect. By combining the findings from these two directions of causal logic (i.e. union density's impact on social expenditure, and social expenditure's impact on union 
density), the results of this research suggest that trade unions are better able to impact upon policy in coordinated political economies.

In sum, the reciprocal relation between trade union density and social expenditure in the present study suggests the occurrence of a positive feedback cycle with two main components. First, trade union density is associated with a higher level of social expenditure, but only in coordinated market economies. All available empirical studies, however, strongly suggest that trade union membership has systematically weakened in recent years (Bryson, Ebbinghaus, and Visser 2011). While this decline has taken place in democratic political systems of all kinds, it seems that liberal market economies have experienced the greatest decline in trade union membership over the past five decades (Schmitt and Mitukiewicz 2012). The results of the current analysis therefore suggest that political decision makers now are less strongly exposed to social pressure to allocate resources to social expenditure. In this manner, the weakening of trade unions can be related to a trend to reduce levels of social protection. The second component of the cycle is a powerful feedback effect whereby trade unions benefit greatly from high levels of social expenditure. Although this direction of the feedback effect is rarely studied in the empirical literature, the analytical models that investigated cross-country and within country effects, including a time lag, showed a large and significant effect of social expenditure on union density. By integrating the results of the feedback effects in both directions, the findings suggest that the mobilization success of trade unions is partly dependent on the opportunities created by contextual political institutions, which could be labeled as a form of 'state unionism'. This feedback effect is theoretically relevant, since studies of liberal and coordinated market economies suggest that the distinctions between these types of capitalism remain salient and may even be increasing (Thelen 2001, 81). Market mechanisms have become even more pronounced in liberal economies just as benefits entitlements have increased in coordinated economies (Hall and Gingerich 2009, 478-479). The theoretical relevance of the 
study is that it allows us a new perspective on why the 'varieties of capitalism' continue to exist without convergence. The two mechanisms we have detected amount to a stable equilibrium. Once non-state actors have an impact on government policy, subsequently they also benefit from this policy to consolidate their power base.

These findings suggest that future research on the effects of collective actors on policy should take into account the opposite feedback effect and not simply presume the common logic that is found in recent large-N empirical studies of the effect of citizen participation on policy. In addition, while the interaction effects of political-economic context suggest different relationships at play in coordinated versus liberal market economies, it is worth repeating that these two types of market economies include a small subset of our overall sample, and future research is required to investigate the effect of more varied types of political economies. Finally, it falls outside the scope of the current article to investigate what kind of mechanism explains why the feedback effect differs by political-economic context. In some countries trade unions are actively involved in administering at least some forms of social expenditure, while one might also speculate that social expenditure and social protection reduce the potential costs and risks associated with trade union membership.

The findings of this study add new insights regarding a feedback loop that may contribute to the increased divergence between types of capitalism: in coordinated market economies high levels of social expenditure encourage trade union mobilization, which, in turn exerts pressure to increase social expenditures; in contrast, liberal economies are characterized by lower levels of social expenditure and low, and even diminishing levels of trade union density. It seems plausible that the financial and economic crisis that began in 2008 may place pressure on this positive feedback loop as governments in numerous OECD countriesincluding coordinated market economies-cut down on social expenditure to reduce 
government benefits. Future research will have to ascertain whether the dynamics we identified are also valid in subsequent times of budgetary and social hardship. 
Biographical notes: Marc Hooghe is a professor of political science at the University of Leuven in Belgium. Jennifer Oser is an Assistant Professor of politics and government at the Ben-Gurion University of the Negev in Israel.

Addresses for correspondence: Marc Hooghe, Centre for Citizenship and Democracy, University of Leuven, Parkstraat 45, B-3000 Leuven, Belgium. email:

marc.hooghe@soc.kuleuven.be / Jennifer Oser, Department of Politics and Government, BenGurion University of the Negev, Building 72, 6th floor, Room 642, Beer Sheva 8410501, Israel. email: oser@post.bgu.ac.il

Funding: The authors wish to thank the European Research Council for the ERC Advanced Grant 295920 on democratic linkage between citizens and the state.

\section{ACKNOWLEDGMENTS}

The authors thank Jeremy Albright, Michael Delli Carpini, Noam Gidron, Jan Leighley, Ronen Mandelkern, Chris Reece and Theda Skocpol for comments on the research. 


\section{NOTES}

1 Of OECD countries, four are not included due to lack of data (Czech Republic,

Estonia, Greece and Switzerland). For the parallel estimation of large OECD nations only we include 22 nations (Australia, Austria, Belgium, Britain, Canada, Denmark, Finland, France, Germany, Greece, Ireland, Italy, Japan, the Netherlands, New Zealand, Norway, Portugal, Spain, Sweden, Switzerland, Turkey, U.S.). Countries like Luxembourg and Iceland are not included due to their small size, and countries like Mexico are not included because of their low GDP/capita (Hall and Soskice 2001, 1921).

2 The variance inflation factor (VIF) for trade union is 17.85; the average VIF for all items in the model is lower than 10. 


\section{REFERENCES}

Beck, N. and J. Katz. 1995. "What to Do (and Not to Do) with Time-Series Cross-Section Data." American Political Science Review 89 (3):634-647.

Béland, D. 2001. Does Labor Matter? Institutions, Labor Unions and Pension Reform in France and the United States. Journal of Public Policy 21 (2):153-172.

Boeri, T., A. Brugiavini and L. Calmfors, eds. 2001. The Role of Unions in the Twenty-first Century. Oxford: Oxford University Press.

Boreham, P., R. Hall and M. Leet. 1996. "Labour and Citizenship: The Development of Welfare State Regimes." Journal of Public Policy 16 (2):203-227.

Bradley, D., E. Huber, S. Moller, F. Nielsen and J.D. Stephens 2003. "Distribution and Redistribution in Postindustrial Democracies." World Politics 55 (2):193-228.

Bryson, A., B. Ebbinghaus and J. Visser. 2011. "Introduction: Causes, Consequences and Cures of Union Decline." European Journal of Industrial Relations 17 (2):97-105.

Campbell, A. 2003. How Policies Make Citizens: Senior Political Activism and the American Welfare State. Princeton, N.J.: Princeton University Press.

Castles, F. and H. Obinger. 2007. Social expenditure and the politics of redistribution. Journal of European Social Policy 17(3): 206-222.

Checchi, D. and L. Nunziata. 2011. "Models of Unionism and Unemployment." European Journal of Industrial Relations 17 (2):141-152.

Cheon, A. and J. Urpelainen. 2013. "How Do Competing Interest Groups Influence Environmental Policy? The Case of Renewable Electricity in Industrialized Democracies, 1989-2007." Political Studies 61 (4):874-897.

De Deken, J. and B. Kittel. 2007. "Social Expenditure under Scrutiny: The Problems of Using Aggregate Spending Data for Assessing Welfare State Dynamics." In Investigating Welfare State Change, edited by Jochen Clasen and Nico Siegel, 72-105.

Donado, A. and K. Wälde. 2012. "How trade unions increase welfare." Economic Journal 122(563): 990-1009.

Driscoll, J. and A. Kraay. 1998. "Consistent Covariance Matrix Estimation with Spatially Dependent Panel Data." Review of Economics and Statistics 80 (4):549-560.

Ebbinghaus, B., C. Gobel and S. Koos. 2011. Social capital, 'Ghent' and workplace contexts matter: Comparing union membership in Europe. European Journal of Industrial Relations 17(2): 107-124.

Evans, P.B., D. Rueschemeyer and T. Skocpol, eds. 1985. Bringing the State Back In. Cambridge: Cambridge University Press. 
Flavin, P. and B. Radcliff. 2011. Labor Union Membership and Voting across Nations. Electoral Studies 30 (4):633-641.

Golden, M. 1993. "The Dynamics of Trade Unionism and National Economic Performance." American Political Science Review 87 (2):437-454.

Gumbrell-McCormick, R. and R. Hyman. 2013. Trade Unions in Western Europe:Hard Times, Hard Choices. Oxford: Oxford University Press.

Hall, P. A. and D. Gingerich. 2009. "Varieties of Capitalism and Institutional Complementarities in the Political Economy: An Empirical Analysis." British Journal of Political Science 39 (3):449-482.

Hall, P. A. and D. Soskice. 2001. "An Introduction to Varieties of Capitalism". In Varieties of Capitalism: The Institutional Foundations of Comparative Advantage, edited by Peter A. Hall and David Soskice. Oxford: Oxford University Press, 1-68.

Hayter, S. and V. Stoevska. 2011. "Social Dialogue Indicators: International Statistical Inquiry, 2008-2009.” Geneva: International Labor Office.

Hicks, A. M. and D. Swank. 1992. "Politics, Institutions, and Welfare Spending in Industrialized Democracies, 1960-1982." American Political Science Review 86 (3):658-674.

Hill, K. Q., J.E. Leighley and A. Hinton-Andersson. 1995. "Lower-Class Mobilization and Policy Linkage in the U.S. States." American Journal of Political Science 39 (1):7586.

Hooghe, M. and C. Meeusen. 2013. "Is same-sex marriage legislation related to attitudes toward homosexuality?" Sexuality Research and Social Policy 10 (4):258-268.

Howell, C. 2003. Varieties of capitalism: And then there was one? Comparative Politics 36 (1):103-124.

Htun, M. and S.L. Weldon. 2012. "The Civic Origins of Progressive Policy Change: Combating Violence against Women in Global Perspective, 1975-2005." American Political Science Review 106 (3):548-569.

Iversen, T. 2008. Economic Shocks and Varieties of Government Reponses. In Beyond Varieties of Capitalism, edited by B. Hancké, M. Rhodes and M. Thatcher. Oxford: Oxford University Press.

International Labor Organization. 2013. Main Statistics (annual) - Strikes and lockouts. http://laborsta.ilo.org/applv8/data/c9e.html

(Retrieved March 7, 2013)

Jensen, Carsten. 2011. "Negotiated expansion: Left-wing governments, corporatism and social expenditure in mature welfare states." Comparative European Politics 9(2): 168-190. 
Jensen, Carsten. 2012. "Two Sides of the Same Coin? Left-Wing Governments and Labour Unions as Determinants of Public Spending." Socio-Economic Review 10 (2):217-240.

Keefer, P. 2013. Database of Political Institution 2012 - Updated January 2013. http://econ.worldbank.org/WBSITE/EXTERNAL/EXTDEC/EXTRESEARCH/0,,cont entMDK:20649465 pagePK:64214825 piPK:64214943 theSitePK:469382,00.html (March 7, 2013)

Kittel, B. and H. Obinger. 2003. Political parties, institutions, and the dynamics of social expenditure in times of austerity. Journal of European Public Policy 10(1): 20-45.

Korpi, W. 1989. "Power, Politics, and State Autonomy in the Development of Social Citizenship." American Sociological Review 54 (3):309-328.

Kuitto, K. 2011. "More Than Just Money: Patterns of Disaggregated Welfare Expenditure in the Enlarged Europe." Journal of European Social Policy 21(4): 348-64.

Larcinese, V. 2007. "Voting over Redistribution and the Size of the Welfare State: The Role of Turnout." Political Studies 55 (3):568-585.

Leighley, J.E. and J. Nagler. 2007. "Unions, Voter Turnout, and Class Bias in the U.S. Electorate, 1964-2004." The Journal of Politics 69 (2):430-441.

Lindvall, J. 2013. "Union Density and Political Strikes." World Politics 65 (3):539-569.

McBride, D. and A. Mazur, eds. 1995. Comparative State Feminism. Thousand Oaks: Sage.

Molina, O. and M. Rhodes. 2002. "Corporatism: The Past, Present, and Future of a Concept." Annual Review of Political Science 5: 305-331.

OECD. 2011. Divided we stand. Paris: OECD Publishing.

OECD. 2014. Social Expenditure Database (SOCX): Public Social Expenditure Data by Broad Category. Last accessed: June 13, 2014 http://www.oecd.org/els/soc/Annex-Tables-SpendingByBroadCategory-Revised.xls

Pierson, P. 1994. Dismantling the Welfare State? Reagan, Thatcher, and the Politics of Retrenchment. New York: Cambridge University Press.

Pierson, P. 2000. Increasing Returns, Path Dependence, and the Study of Politics. American Political Science Review 94 (2):251-267.

Pontusson, J. 2013. Unionization, Inequality and Redistribution. British Journal of Industrial Relations 51 (4):797-825.

Radcliff, B. and P. Davis. 2000. "Labor Organization and Electoral Participation in Industrial Democracies." American Journal of Political Science 44 (1):132-141.

Regini, M., and G. Esping-Andersen. 1980. "Trade Union Strategies and Social Policy in Italy and Sweden." West European Politics 3 (1): 107-123. 
Richardson, J. 2000. "Government, interest groups and policy change." Political Studies 48 (5): 1006-1025.

Schmitt, John, and Alexandra Mitukiewicz. 2012. "Politics Matter: Changes in Unionisation Rates in Rich Countries, 1960-2010." Industrial Relations Journal 43 (3):260-280.

Siegel, N. A. 2007. When (only) money matters: the pros and cons of expenditure analysis. In J. Clasen, \& N. A. Siegel (Eds.), Investigating welfare state change: The 'dependent variable problem' in comparative analysis (pp. 43-71). Cheltenham: Edward Elgar.

Swank, D. 1988. "The Political Economy of Government Domestic Expenditure in the Affluent Democracies, 1960-80." American Journal of Political Science 32 (4):11201150 .

Thelen, K. 2001. "Varieties of Labor Politics in the Developed Democracies". In Varieties of Capitalism, edited by P. Hall and D. Soskice. Oxford: Oxford University Press, 72103.

Thelen, K. 2012. "Varieties of Capitalism: Trajectories of Liberalization and the New Politics of Social Solidarity." Annual Review of Political Science 15:137-159.

Van Rie, T., I. Marx, and J. Horemans. 2011. Ghent Revisited: Unemployment Insurance and Union Membership in Belgium and the Nordic Countries. European Journal of Industrial Relations 17 (2):125-139.

Visser, J. 2013. ICTWSS: Database on Institutional Characteristics of Trade Unions, Wage Setting, State Interventions and Social Pacts; Version 3.0. http://www.uva-aias.net/207 (March 7, 2013)

Wooldridge, J. M. 2010. Econometric analysis of cross section and panel data. Cambridge: MIT Press.

Zárate Tenorio, B. 2014. Social Spending Responses to Organized Labor and Mass Protests in Latin America, 1970-2007. Comparative Political Studies 47 (14):1945-1972. 
Table 1. Estimated Determinants of Social Expenditure Pooled random effects OLS regression models

\begin{tabular}{|c|c|c|c|c|c|c|}
\hline & (1) & (2) & (3) & (4) & (5) & (6) \\
\hline Union density & $\begin{array}{c}0.120^{* * * *} \\
(0.011)\end{array}$ & & $\begin{array}{c}0.103 * * * \\
(0.006)\end{array}$ & & & \\
\hline Union density $\mathrm{t}-1$ & & $\begin{array}{c}0.124 * * * \\
(0.012)\end{array}$ & & $\begin{array}{c}0.104 * * * \\
(0.007)\end{array}$ & $\begin{array}{c}0.126^{* * * *} \\
(0.008)\end{array}$ & $\begin{array}{c}0.069 * * * \\
(0.013)\end{array}$ \\
\hline Left party & $\begin{array}{c}1.540^{* * * *} \\
(0.405)\end{array}$ & $\begin{array}{c}1.588^{* * * *} \\
(0.423)\end{array}$ & $\begin{array}{c}0.692 * * \\
(0.327)\end{array}$ & $\begin{array}{c}0.749^{* *} \\
(0.332)\end{array}$ & $\begin{array}{c}0.753^{* * *} \\
(0.300)\end{array}$ & $\begin{array}{c}0.647 * * \\
(0.296)\end{array}$ \\
\hline Voter turnout & $\begin{array}{l}0.032^{*} \\
(0.016)\end{array}$ & $\begin{array}{c}0.025 \\
(0.018)\end{array}$ & $\begin{array}{c}0.020 \\
(0.023)\end{array}$ & $\begin{array}{c}0.021 \\
(0.025)\end{array}$ & $\begin{array}{c}0.098 * * * \\
(0.027)\end{array}$ & $\begin{array}{c}0.148 * * * \\
(0.022)\end{array}$ \\
\hline GDP per capita & $\begin{array}{c}0.106 * * * \\
(0.023)\end{array}$ & $\begin{array}{c}0.104 * * * \\
(0.022)\end{array}$ & $\begin{array}{c}-0.118^{* * * *} \\
(0.017)\end{array}$ & $\begin{array}{c}-0.116^{* * * *} \\
(0.017)\end{array}$ & $\begin{array}{c}-0.195^{* * * *} \\
(0.041)\end{array}$ & $\begin{array}{c}-0.118^{* * * *} \\
(0.037)\end{array}$ \\
\hline GDP growth & $\begin{array}{c}- \\
0.645^{* * * *} \\
(0.094)\end{array}$ & $\begin{array}{c}-0.666^{* * *} \\
(0.096)\end{array}$ & $\begin{array}{c}-0.156^{* *} \\
(0.057)\end{array}$ & $\begin{array}{c}-0.170^{* * *} \\
(0.059)\end{array}$ & $\begin{array}{c}-0.244 * * * \\
(0.053)\end{array}$ & $\begin{array}{c}-0.281 * * * \\
(0.062)\end{array}$ \\
\hline Year & $\begin{array}{c}0.129 * * * \\
(0.024)\end{array}$ & $\begin{array}{c}0.120 * * * \\
(0.023)\end{array}$ & $\begin{array}{l}-0.019 \\
(0.014)\end{array}$ & $\begin{array}{l}-0.016 \\
(0.017)\end{array}$ & $\begin{array}{c}0.065 * * * \\
(0.022)\end{array}$ & $\begin{array}{c}0.069 * * * \\
(0.018)\end{array}$ \\
\hline Agriculture & & & $\begin{array}{c}-0.504 * * * \\
(0.085)\end{array}$ & $\begin{array}{c}-0.502 * * * \\
(0.089)\end{array}$ & $\begin{array}{c}-0.720 * * * \\
(0.058)\end{array}$ & $\begin{array}{c}-0.477 * * * \\
(0.075)\end{array}$ \\
\hline Industry & & & $\begin{array}{c}-0.236 * * * \\
(0.020)\end{array}$ & $\begin{array}{c}-0.233 * * * \\
(0.019)\end{array}$ & $\begin{array}{c}-0.379 * * * \\
(0.046)\end{array}$ & $\begin{array}{c}-0.221 * * * \\
(0.031)\end{array}$ \\
\hline Minerals & & & $\begin{array}{l}-0.103 \\
(0.064)\end{array}$ & $\begin{array}{l}-0.108 \\
(0.067)\end{array}$ & $\begin{array}{l}-0.294 \\
(0.258)\end{array}$ & $\begin{array}{c}-0.963 * * \\
(0.363)\end{array}$ \\
\hline Trade & & & $\begin{array}{c}0.011 * * * \\
(0.003)\end{array}$ & $\begin{array}{c}0.011^{* * *} * \\
(0.003)\end{array}$ & $\begin{array}{l}-0.002 \\
(0.005)\end{array}$ & $\begin{array}{c}0.007 \\
(0.006)\end{array}$ \\
\hline Urban population & & & $\begin{array}{l}-0.005 \\
(0.020)\end{array}$ & $\begin{array}{l}-0.005 \\
(0.022)\end{array}$ & $\begin{array}{c}-0.194 * * * \\
(0.015)\end{array}$ & $\begin{array}{c}-0.197 * * * * \\
(0.012)\end{array}$ \\
\hline Unemployment rate & & & $\begin{array}{c}0.343 * * * \\
(0.021)\end{array}$ & $\begin{array}{c}0.342^{* * * *} \\
(0.021)\end{array}$ & $\begin{array}{c}0.326 * * * \\
(0.040)\end{array}$ & $\begin{array}{c}0.252^{* * * *} \\
(0.046)\end{array}$ \\
\hline Old age & & & $\begin{array}{c}1.045 * * * \\
(0.075)\end{array}$ & $\begin{array}{c}1.031 * * * \\
(0.078)\end{array}$ & $\begin{array}{c}0.788 * * * \\
(0.066)\end{array}$ & $\begin{array}{c}0.941 * * * \\
(0.064)\end{array}$ \\
\hline CME & & & & & $\begin{array}{c}2.691 * * * \\
(0.515)\end{array}$ & \\
\hline Ghent & & & & & & $\begin{array}{c}3.693 * * * \\
(0.411)\end{array}$ \\
\hline Constant & $\begin{array}{c}9.836 * * * \\
(1.331)\end{array}$ & $\begin{array}{c}10.521 * * * \\
(1.410)\end{array}$ & $\begin{array}{c}9.525 * * * \\
(1.533)\end{array}$ & $\begin{array}{c}9.476 * * * \\
(1.534)\end{array}$ & $\begin{array}{c}23.552 * * * \\
(3.071)\end{array}$ & $\begin{array}{c}16.461 \text { *** } \\
(2.874)\end{array}$ \\
\hline Observations & 712 & 680 & 657 & 638 & 419 & 419 \\
\hline R-squared & 0.344 & 0.349 & 0.789 & 0.786 & 0.886 & 0.880 \\
\hline Number of groups & 30 & 29 & 29 & 28 & 17 & 17 \\
\hline
\end{tabular}

Note: Standard errors in parentheses. Sign.: $* * * p<0.01, * * p<0.05, * p<0.1$ 
Table 2. Estimated Determinants of Social Expenditure Country fixed effects regression models

\begin{tabular}{|c|c|c|c|c|}
\hline & $(1)$ & $(2)$ & (3) & (4) \\
\hline Union density & $\begin{array}{c}0.067 * * \\
(0.024)\end{array}$ & & $\begin{array}{c}0.053 * * * \\
(0.017)\end{array}$ & \\
\hline Union density $\mathrm{t}-1$ & & $\begin{array}{c}0.046 * * \\
(0.022)\end{array}$ & & $\begin{array}{c}0.032 * * \\
(0.014)\end{array}$ \\
\hline Left party & $\begin{array}{l}-0.190 \\
(0.288)\end{array}$ & $\begin{array}{c}-0.251 \\
(0.297)\end{array}$ & $\begin{array}{l}-0.378 \\
(0.266)\end{array}$ & $\begin{array}{l}-0.394 \\
(0.275)\end{array}$ \\
\hline Voter turnout & $\begin{array}{l}-0.001 \\
(0.014)\end{array}$ & $\begin{array}{l}-0.012 \\
(0.015)\end{array}$ & $\begin{array}{c}0.010 \\
(0.011)\end{array}$ & $\begin{array}{c}0.010 \\
(0.012)\end{array}$ \\
\hline GDP per capita & $\begin{array}{c}-0.273 * * * \\
(0.036)\end{array}$ & $\begin{array}{c}-0.281 * * * \\
(0.037)\end{array}$ & $\begin{array}{c}-0.083 * * * \\
(0.028)\end{array}$ & $\begin{array}{c}-0.081 * * \\
(0.031)\end{array}$ \\
\hline GDP growth & $\begin{array}{c}-0.215^{* * *} \\
(0.048)\end{array}$ & $\begin{array}{c}-0.223 * * * \\
(0.049)\end{array}$ & $\begin{array}{c}-0.102 * * \\
(0.037)\end{array}$ & $\begin{array}{c}-0.103 * * * \\
(0.037)\end{array}$ \\
\hline Year & $\begin{array}{c}0.301 * * * \\
(0.030)\end{array}$ & $\begin{array}{c}0.285 * * * \\
(0.030)\end{array}$ & $\begin{array}{c}0.094 * * * \\
(0.018)\end{array}$ & $\begin{array}{c}0.084 * * * \\
(0.021)\end{array}$ \\
\hline Agriculture & & & $\begin{array}{c}-0.510 * * * \\
(0.063)\end{array}$ & $\begin{array}{c}-0.498 * * * \\
(0.073)\end{array}$ \\
\hline Industry & & & $\begin{array}{c}-0.189 * * * \\
(0.038)\end{array}$ & $\begin{array}{c}-0.185 * * * \\
(0.041)\end{array}$ \\
\hline Minerals & & & $\begin{array}{c}-0.199 * * * \\
(0.056)\end{array}$ & $\begin{array}{c}-0.197 * * * \\
(0.054)\end{array}$ \\
\hline Trade & & & $\begin{array}{c}-0.035^{* * * *} \\
(0.004)\end{array}$ & $\begin{array}{c}-0.035 * * * \\
(0.004)\end{array}$ \\
\hline Urban population & & & $\begin{array}{c}0.055 \\
(0.036)\end{array}$ & $\begin{array}{c}0.052 \\
(0.039)\end{array}$ \\
\hline Unemployment rate & & & $\begin{array}{c}0.316 * * * \\
(0.029)\end{array}$ & $\begin{array}{c}0.322 * * * \\
(0.032)\end{array}$ \\
\hline Old age & & & $\begin{array}{c}0.312 * * * \\
(0.048)\end{array}$ & $\begin{array}{c}0.331 * * * \\
(0.050)\end{array}$ \\
\hline Constant & $\begin{array}{c}18.513 * * * \\
(1.512)\end{array}$ & $\begin{array}{c}20.643 * * * \\
(1.460)\end{array}$ & $\begin{array}{c}17.378 * * * \\
(3.007)\end{array}$ & $\begin{array}{c}18.086^{* * * *} \\
(3.219)\end{array}$ \\
\hline Observations & 712 & 680 & 657 & 638 \\
\hline Number of groups & 30 & 29 & 29 & 28 \\
\hline
\end{tabular}

Note: Standard errors in parentheses. Sign.: *** $\mathrm{p}<0.01, * * \mathrm{p}<0.05, * \mathrm{p}<0.1$ 
Table 3. Estimated Determinants of Union Density Pooled ordinary least squares regression models

\begin{tabular}{|c|c|c|c|c|c|c|}
\hline & (1) & (2) & (3) & (4) & $(5)$ & $(6)$ \\
\hline Social expend. (SE) & $\begin{array}{c}1.251 * * * \\
(0.056)\end{array}$ & & $\begin{array}{c}2.089 * * * \\
(0.195)\end{array}$ & & & \\
\hline $\mathrm{SE}_{\mathrm{t}-1}$ & & $\begin{array}{c}1.207 * * * \\
(0.055)\end{array}$ & & $\begin{array}{c}2.036 * * * \\
(0.173)\end{array}$ & $\begin{array}{c}2.747 * * * \\
(0.266)\end{array}$ & $\begin{array}{c}0.751^{* * *} * \\
(0.145)\end{array}$ \\
\hline Left party & $\begin{array}{l}-0.504 \\
(1.264)\end{array}$ & $\begin{array}{l}-0.809 \\
(1.292)\end{array}$ & $\begin{array}{c}1.523 \\
(1.384)\end{array}$ & $\begin{array}{c}1.206 \\
(1.315)\end{array}$ & $\begin{array}{c}2.976 * * * \\
(0.937)\end{array}$ & $\begin{array}{c}4.086 * * * \\
(0.803)\end{array}$ \\
\hline Voter turnout & $\begin{array}{c}0.395 * * * \\
(0.043)\end{array}$ & $\begin{array}{c}0.388 * * * \\
(0.044)\end{array}$ & $\begin{array}{c}0.046 \\
(0.042)\end{array}$ & $\begin{array}{c}0.014 \\
(0.039)\end{array}$ & $\begin{array}{c}-0.204 * * \\
(0.082)\end{array}$ & $\begin{array}{c}0.297 * * * \\
(0.060)\end{array}$ \\
\hline GDP per capita & $\begin{array}{c}0.464 * * * \\
(0.053)\end{array}$ & $\begin{array}{c}0.467 * * * \\
(0.053)\end{array}$ & $\begin{array}{c}0.778 * * * \\
(0.040)\end{array}$ & $\begin{array}{c}0.752 * * * \\
(0.045)\end{array}$ & $\begin{array}{c}1.488 * * * \\
(0.089)\end{array}$ & $\begin{array}{c}1.448 * * * \\
(0.108)\end{array}$ \\
\hline GDP growth & $\begin{array}{c}0.599 * * \\
(0.254)\end{array}$ & $\begin{array}{c}0.327 \\
(0.291)\end{array}$ & $\begin{array}{l}-0.045 \\
(0.269)\end{array}$ & $\begin{array}{l}-0.459 \\
(0.274)\end{array}$ & $\begin{array}{l}-0.254 \\
(0.310)\end{array}$ & $\begin{array}{l}-0.289 \\
(0.258)\end{array}$ \\
\hline Year & $\begin{array}{c}-0.686^{* * * *} \\
(0.040)\end{array}$ & $\begin{array}{c}-0.677 * * * \\
(0.043)\end{array}$ & $\begin{array}{c}-0.420 * * * \\
(0.081)\end{array}$ & $\begin{array}{c}-0.476 * * * \\
(0.080)\end{array}$ & $\begin{array}{c}-0.742 * * * \\
(0.083)\end{array}$ & $\begin{array}{c}-0.317 * * * \\
(0.095)\end{array}$ \\
\hline Agriculture & & & $\begin{array}{c}4.184 * * * \\
(0.295)\end{array}$ & $\begin{array}{c}4.242 * * * \\
(0.298)\end{array}$ & $\begin{array}{c}5.945 * * * \\
(0.323)\end{array}$ & $\begin{array}{c}4.795^{* * * *} \\
(0.337)\end{array}$ \\
\hline Industry & & & $\begin{array}{c}1.587 * * * \\
(0.122)\end{array}$ & $\begin{array}{c}1.566^{* * * *} \\
(0.115)\end{array}$ & $\begin{array}{c}1.512 * * * \\
(0.116)\end{array}$ & $\begin{array}{c}0.999 * * * \\
(0.072)\end{array}$ \\
\hline Minerals & & & $\begin{array}{l}-0.632 * \\
(0.310)\end{array}$ & $\begin{array}{l}-0.513^{*} \\
(0.257)\end{array}$ & $\begin{array}{c}0.802 \\
(0.588)\end{array}$ & $\begin{array}{c}-1.078^{* *} \\
(0.440)\end{array}$ \\
\hline Trade & & & $\begin{array}{c}0.082 * * * \\
(0.010)\end{array}$ & $\begin{array}{c}0.084 * * * \\
(0.009)\end{array}$ & $\begin{array}{c}0.141 * * * \\
(0.024)\end{array}$ & $\begin{array}{c}0.107 * * * \\
(0.018)\end{array}$ \\
\hline Urban population & & & $\begin{array}{c}0.566 * * * \\
(0.047)\end{array}$ & $\begin{array}{c}0.576 * * * \\
(0.050)\end{array}$ & $\begin{array}{c}1.016 * * * \\
(0.064)\end{array}$ & $\begin{array}{c}0.245 * * * \\
(0.055)\end{array}$ \\
\hline Unemployment rate & & & $\begin{array}{c}-0.982 * * * \\
(0.174)\end{array}$ & $\begin{array}{c}-1.081 * * * \\
(0.164)\end{array}$ & $\begin{array}{l}-0.003 \\
(0.314)\end{array}$ & $\begin{array}{c}0.823 * * * \\
(0.168)\end{array}$ \\
\hline Old age & & & $\begin{array}{c}0.488 \\
(0.531)\end{array}$ & $\begin{array}{c}0.566 \\
(0.535)\end{array}$ & $\begin{array}{l}-0.455 \\
(0.790)\end{array}$ & $\begin{array}{l}-0.058 \\
(0.482)\end{array}$ \\
\hline CME & & & & & $\begin{array}{c}2.816^{* * *} \\
(1.307)\end{array}$ & \\
\hline Ghent & & & & & & $\begin{array}{c}29.864 * * * \\
(1.358)\end{array}$ \\
\hline Constant & $\begin{array}{c}-16.945 * * * \\
(3.852)\end{array}$ & $\begin{array}{c}-14.704 * * * \\
(4.220)\end{array}$ & $\begin{array}{c}-130.046^{* * *} \\
(10.299)\end{array}$ & $\begin{array}{c}-124.142 * * * \\
(10.611)\end{array}$ & $\begin{array}{c}-165.861 * * * \\
(11.909)\end{array}$ & $\begin{array}{c}-109.734 * * * \\
(12.098)\end{array}$ \\
\hline Observations & 712 & 684 & 657 & 639 & 417 & 417 \\
\hline R-squared & 0.373 & 0.368 & 0.609 & 0.608 & 0.770 & 0.875 \\
\hline Number of groups & 30 & 30 & 29 & 29 & 17 & 17 \\
\hline
\end{tabular}

Note: Standard errors in parentheses. Sign.: *** $\mathrm{p}<0.01, * * \mathrm{p}<0.05, * \mathrm{p}<0.1$ 
Table 4. Estimated Determinants of Union Density Country fixed effects regression models

\begin{tabular}{|c|c|c|c|c|}
\hline & $(1)$ & (2) & (3) & (4) \\
\hline Social expend. (SE) & $\begin{array}{c}0.463 * * * \\
(0.149)\end{array}$ & & $\begin{array}{c}0.421 * * * \\
(0.117)\end{array}$ & \\
\hline $\mathrm{SE}_{\mathrm{t}-1}$ & & $\begin{array}{c}0.422 * * * \\
(0.127)\end{array}$ & & $\begin{array}{c}0.402 * * * \\
(0.110)\end{array}$ \\
\hline Left party & $\begin{array}{l}-0.066 \\
(0.619)\end{array}$ & $\begin{array}{l}-0.051 \\
(0.611)\end{array}$ & $\begin{array}{c}0.842 * * \\
(0.385)\end{array}$ & $\begin{array}{c}0.806^{* *} \\
(0.388)\end{array}$ \\
\hline Voter turnout & $\begin{array}{c}0.044 \\
(0.036)\end{array}$ & $\begin{array}{c}0.034 \\
(0.033)\end{array}$ & $\begin{array}{c}0.014 \\
(0.029)\end{array}$ & $\begin{array}{l}-0.002 \\
(0.031)\end{array}$ \\
\hline GDP per capita & $\begin{array}{c}0.169 * * \\
(0.076)\end{array}$ & $\begin{array}{c}0.109 \\
(0.073)\end{array}$ & $\begin{array}{c}0.101 \\
(0.075)\end{array}$ & $\begin{array}{c}0.065 \\
(0.075)\end{array}$ \\
\hline GDP growth & $\begin{array}{l}-0.069 \\
(0.070)\end{array}$ & $\begin{array}{c}-0.137 * * \\
(0.064)\end{array}$ & $\begin{array}{l}-0.077 \\
(0.081)\end{array}$ & $\begin{array}{c}-0.165^{* *} \\
(0.078)\end{array}$ \\
\hline Year & $\begin{array}{c}-0.684 * * * \\
(0.060)\end{array}$ & $\begin{array}{c}-0.647 * * * \\
(0.057)\end{array}$ & $\begin{array}{c}-0.339 * * * \\
(0.105)\end{array}$ & $\begin{array}{c}-0.326 * * * \\
(0.109)\end{array}$ \\
\hline Agriculture & & & $\begin{array}{c}1.281 * * * \\
(0.189)\end{array}$ & $\begin{array}{c}1.262 * * * \\
(0.197)\end{array}$ \\
\hline Industry & & & $\begin{array}{c}0.441 * * * \\
(0.108)\end{array}$ & $\begin{array}{c}0.406^{* * *} * \\
(0.116)\end{array}$ \\
\hline Minerals & & & $\begin{array}{c}-0.103 \\
(0.150)\end{array}$ & $\begin{array}{l}-0.115 \\
(0.162)\end{array}$ \\
\hline Trade & & & $\begin{array}{l}-0.017 \\
(0.012)\end{array}$ & $\begin{array}{c}-0.011 \\
(0.012)\end{array}$ \\
\hline Urban population & & & $\begin{array}{c}0.370 * * * \\
(0.080)\end{array}$ & $\begin{array}{c}0.280 * * * \\
(0.081)\end{array}$ \\
\hline Unemployment rate & & & $\begin{array}{c}0.259 * * \\
(0.101)\end{array}$ & $\begin{array}{l}0.206^{*} \\
(0.104)\end{array}$ \\
\hline Old age & & & $\begin{array}{c}0.081 \\
(0.160)\end{array}$ & $\begin{array}{c}0.096 \\
(0.164)\end{array}$ \\
\hline Constant & $\begin{array}{c}32.979 * * * \\
(3.815)\end{array}$ & $\begin{array}{c}35.219 * * * \\
(3.272)\end{array}$ & $\begin{array}{c}-17.325 * \\
(9.535)\end{array}$ & $\begin{array}{l}-7.080 \\
(8.806)\end{array}$ \\
\hline Observations & 712 & 684 & 657 & 639 \\
\hline Number of groups & 30 & 30 & 29 & 29 \\
\hline
\end{tabular}

Note: Standard errors in parentheses. Sign.: *** $\mathrm{p}<0.01$, $* * \mathrm{p}<0.05, * \mathrm{p}<0.1$ 
Figure 1. Predicted Social Expenditure by Union Density

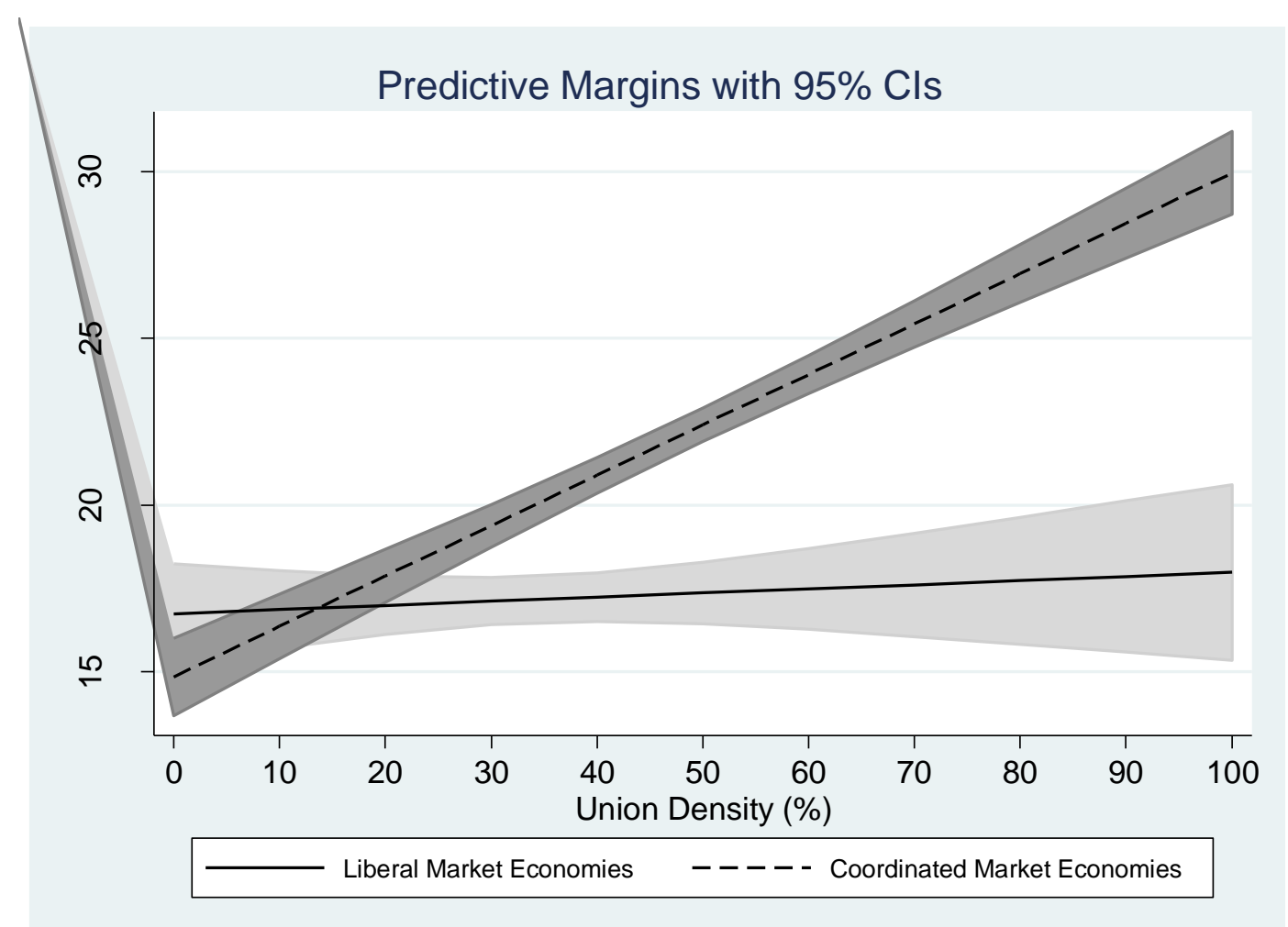

